\title{
Nordic Museology
}

The five Nordic countries - Denmark, Finland, Iceland, Norway and Sweden share a common cultural history. Four of them are closely related linguistically. Through the ages they have also been politically linked in a variety of combinations, causing both dramatic confrontations and inspiring nationalistic movements not without bearing on the museum history of the countries. The most lasting political unions were those between Denmark, Iceland and Norway (13801814; Iceland stayed with Denmark until 1944) and between Finland and Sweden (1323-1809). In times of aggression from the 'outside' a loyalty between the Nordic countries based on the common history has also appeared and in the years after 1945 formal organisations have been established to promote cooperation in various fields of common interest.

Denmark, being situated on the Continent, has served through the ages as the mediator of European cultural influences. Thus the first proper museum ideas were undoubtedly introduced by Ole Worm (1588-1654) in Copenhagen who had adopted them during his years of peregrination as a student at Italian universities and visitor to other European centres of learning. Worm carried on a lively correspondence not only with scholars all over the continent, but also with the clergy in the Nordic countries inspiring them to collect, observe and take notes. The catalogue of his collection, Museum Wormianum, was published in 1655 and stands out as one of the earliest museological handbooks, which was eagerly studied and, with its distinction between artificalia and naturalia, was used for the ordering of collections for many years to come.

In the 18th century the Swede Carl von Linné (1707-1778) played a similar exemplary role with his passion for classification and untiring curiosity making him one of the great proponents of Enlightenment. He also took a vivid interest in and wrote directions for the setting up of natural history collections. The dedication to ordering and systematics also gave the Dane Christian Jürgensen Thomsen (1788-1865) an epoch-making role in the understanding of prehistory. Busy with the sorting of prehistoric collections in Copenhagen - later to become 
NORDISK MUSEOLOGI $1995 \cdot 2$

2 the National Museum - he grouped them according to material and proposed that different materials represented different stages of technological development. The concepts stone, bronze and iron age were born and published in Ledetraad til nordisk oldkyndighed ('Guidebook to Nordic Antiquity', 1836). Thomsen like Worm has left a rich correspondence behind which mirrors the important inspiration he gave to emerging museum projects all over Scandinavia.

In the late 19th century a Scandinavian movement swept the Nordic universities. Artur Hazelius (1833-1901) became greatly inspired and - after a visit to the province of Dalecarlia - he decided to devote himself to the creation of a museum, which was to illustrate the common roots of Scandinavian culture. In 1873 he opened the Scandinavian Ethnographic collections in Stockholm, which were later to become the Nordic Museum, and in 1891 the famous open-air museum Skansen. Hazelius was also deeply influenced by the ideas of popular education and his contribution to the museological development was based in his ambition to make everyone aware of the permanent values in the national cultural heritage.

The four names given above are there just to remind us of important Nordic contributors to the history of museums. In the case of Worms and Linné a scientific search was the incentive for collecting and exhibiting, in the case of Thomsen and Hazelius their scholarly ambitions were linked with a romantic nationalism and an idealistic desire to foster and educate their countrymen. The two ideas run together through Nordic museum history and are easily recognized in the title, Memory and Popular Education, of the State Report on museums published last year in Sweden. An ordered and accessible memory and an outreach attracting all citizens are the ideals which govern museum politics.

When, two years ago, it was decided to start NORDISK MUSEOLOGI, the decision was based on the conviction that a common forum was needed in Scandinavia to promote the idea of museology. The journal is now a genuine Nordic enterprise with five editors and an editorial board representing the five 
countries. The editing responsibility is at present located in Sweden, it is printed in Norway and distributed from Denmark.

A primary objective has been to further museology as a much needed university discipline. John Aage Gjestrum gives a background and describes the current situation in the first article in this issue.

But there was also the conviction that the concept of Nordic museology had a special relevance because of the shared cultural history of the countries and the constant flow of ideas crossing the borders and linking the museum makers in the various countries. The connectedness will certainly stand out in many of the contributions here. It is clearly reflected in the overview of Icelandic museum development given by Helgi Sigundsson. The educative theme with its core of national and cultural complexity is dealt with by Mette Skougaard and Tönis Lukas. Maria Björkroth discusses the concept of hembygd. Its affinity is apparent to the local history movement in Finland treated by Hannu Lahtonen and to the folkhøjskole, touched upon by Ole Strandgaard. More concrete are the problems of cultural memory and its communication in the papers by Jan Garnert, Marc Maure and Hans Pedersen.

The traditional classification theme is present in Bente Wolffs, Eva Silvéns and Jette Sandabls articles. The wider scope of contemporary museological networks is mirrored in the papers by Su Donghai and Elisabet Olofsson. And John Aage Gjestrum explores the Nordic involvement in ICOM work as reflected in UNESCO's journal «Museum».

Finally homage is paid to Albert Eide Parr, the Norwegian, who emigrated from Bergen and made an impressive museum career in the United States, culminating in the Directorship of the prestigious Natural History Museum in New York and Presidency of the American Association of Museums. Three extracts from texts by Parr are presented as the traditional Classic regurlarly appearing in the journal.

We are proud to present this issue of our biannual journal in time for the ICOM General Conference in Stavanger. The theme of the conference is Museum and Communities. The role of history and heritage in European culture and society is 
NORDISK MUSEOLOGI $1995 \cdot 2$

4 a basic museological preoccupation. It is also a subject of general concern in our age of political and ethnic unrest and upheaval. The editors are convinced that all the authors represented on the following pages in a way, fruitful to the procedings of the conference, contribute to elucidate important aspects of that central theme.

All the articles are offered in English to make them available to as many as possible of the participants in the conference. This in accordance with the editorial programme which states as an objective to make Scandinavian museological writing known internationally. For the same reason in all issues published to date English summaries are given of articles in Scandinavian languages. The editors are also eager to point out that the journal can boast a massive Nordic support both from the museum associations of the various countries and the Nordic Publications Committee for Humanist Periodicals.

The founding fathers of the journal are especially pleased to have this opportunity to acknowledge the inspiration and fruitful impulses they have received through the years from participation in the work of the international committees of ICOM, the contacts with the Documentation Centre in Paris as well as with the executive staff of the organisation.

Per-Uno Agren

Mrs Patricia Shrimpton at the Department of English at Umea University has been extremely helpful and patient in assisting the editors with supervising the English versions of the original texts. However she cannot be blamed for inadequacies of language caused in the last feverish preparations for printing! 